\title{
PETA PERKEMBANGAN PENELITIAN PEMANFAATAN REPOSITORI INSTITUSI MENUJU OPEN ACCESS: STUDI BIBLIOMETRIK DENGAN VOSVIEWER
}

\author{
Tupan*
}

Pengutipan: Tupan (2016). Peta perkembangan penelitian pemanfaatan repositori institusi menuju open access: studi bibliometrik dengan VOSViewer. Khizanah Al-Hikmah Jurnal Ilmu Perpustakaan, Informasi, dan Kearsipan, 4(2), 104-117.

*Pusat Dokumentasi dan Informasi Ilmiah, Lembaga Ilmu Pengetahuan Indonesia, Jakarta (email: tupan712190@gmail.com)

\begin{abstract}
ABSTRAK
Kajian ini bertujuan untuk mengetahui peta perkembangan penelitian pemanfaatan repositori institusi menuju open access. Kajian dilakukan pada Bulan Agustus 2016 dengan cara melakukan penelusuran melalui database scopus dengan kata kunci open access dan repository institutions. Data hasil penelusuran tersebut kemudian dianalisis secara deskriptif berdasarkan tahun terbit publikasi, nama lembaga dan negara yang mempublikasikan hasil penelitian perkembangan penelitian pemanfaatan repositori institusi menuju open access, nama jurnal/publikasi, tipe dokumen, dan topik penelitian. Untuk mendapatkan peta perkembangan penelitian, data tersebut di-export dalam format CSV (Comma Separated Values) file. Data hasil export kemudian diolah dan dianalisis menggunakan program aplikasi VOSViewer untuk mengetahui peta bibliometrik perkembangan penelitian pemaanfaatan repositori institusi menuju open access. Hasil penelitian menunjukkan bahwa perkembangan penelitian pemanfaatan repositori institusi menuju open access yang terindeks di Scopus sudah ada sejak tahun 1986. Mulai tahun 2002-2016 perkembangannya meningkat secara signifikan. Jurnal yang paling banyak mempublikasikan perkembangan penelitian repositori institusi menuju open access adalah OCLC System and Services, Lecture Notes in Computer Science, Grey Journal, Information Services and Use, Liber Quarterly, Library Review dan Serial Librarian. Dilihat dari jenis/tipe dokumen yang banyak diteliti adalah dalam bentuk artikel disusul conference paper, review dan book chapter. Bidang atau topik yang paling dominan adalah open access, institutional repositorries, societies and institutions, information services, digital libraries, metadata, dan electronic publishing. Melalui visualisasi network menunjukkan bahwa hubungan antartopik diperlihatkan dengan garis antardeskriptor pada masing-masing bidang. Semakin banyak garis hubungan antardeskriptor semakin dekat hubungan antardokumen. Sementara dengan visualisasi density menunjukkan bahwa hubungan antartopik makin merah makin rapat dan makin hijau makin jarang.
\end{abstract}

Kata Kunci: Repositori Institusi, Akses Terbuka, Bibliometrics, VOSViewer, Scopus

\section{ABSTRACT}

The study is aimed to know the development mapping in using open-access institutional repositories. It has been researched in August 2016 by using scopus databases with keywords: open access and institutional repository. The results findings are descriptively analysed according to publication years, institution and country names, journal names, document types, and research topics. To gather the research development mapping, the data were exported by using CSV format (Comma Separated Values). These data then being processed and analysed using VOSViewer application program. 
The study found that the research development mapping have been occurred since 1986. From 20022016, the mapping have been significantly increased. The journals that mostly published its trends were OCLC System and Services, Lecture Notes in Computer Science, Grey Journal, Information Services and Use, Liber Quarterly, Library Review, and Serial Librarian. Meanwhile, the most type of documents were articels, conference paper, review, and book chapters. For the topic of research, it is found that open access, institutional repositories, societies and institutions, information services, digital libraries, metadata, and electronic publishing were dominant. The visual network has shown that the relationship among topics can be seen from descriptor lines in each field. The more relation descriptor lines the closest realtionship among documents.

Keywords: Institutional Repository, Open access, Bibliometrics, VOSViewer, Scopus

\section{PENDAHULUAN}

Repositori adalah tempat penyimpanan bahan-bahan digital yang dihasilkan oleh suatu institusi perguruan tinggi berkaitan erat dengan perubahan yang terjadi dalam pengelolaan sumberdaya informasi di perpustakaan. Perpustakaan sebagai tempat penyimpanan merupakan suatu tempat yang digunakan untuk menyimpan atau merekam koleksi bahan pustaka. Paradigma seperti itu, sudah tertanam dalam benak kita sejak bertahun-tahun yang lalu. Berbagai sumberdaya informasi berbasis kertas (paperbased), yang selama ini merupakan primadona perpustakaan tradisional, sekarang telah banyak tersedia dalam format digital. Kemapanan sumberdaya informasi berbasis kertas ditantang oleh sumber daya informasi digital yang menawarkan cara yang berbeda dalam penyimpanan dan menemubalikkan informasi. Masalah repositori institusi dan open acces sudah ada sejak tahun 1986 seperti yang dikatakan oleh Geselbracht, R.H (1986) bahwa suatu kebijakan akses yang dikembangkan dalam tradisi arsip publik didasarkan pada asumsi bahwa kertas dengan konten kebijakan publik yang tinggi harus terbuka.
Open access memfasilitasi ketersediaan dan distribusi komunikasi ilmiah gratis. Untuk negara berkembang open access menawarkan cara untuk memecahkan masalah keterbatasan akses informasi ilmiah karena kendala keuangan. Masalah yang paling penting bagi sarjana dan peneliti di universitasuniversitas dan organisasi penelitian negara-negara berkembang adalah kurangnya akses current literature. Hasil penelitian yang dihasilkan harus dipublikasikan dalam jurnal dengan biaya tinggi. Selain itu, di negara-negara berkembang infrastruktur untuk penelitian dan kapasitas dalam pengetahuan ilmiah dan teknis masih lemah dan baru dalam taraf pengembangan (Anwarul Islam, 2013).

Penelitian merupakan kegiatan ilmiah yang dilakukan oleh institusi dengan skala besar (negara, pemerintah dan institusi swasta) maupun institusi skala kecil (fakultas, universitas dan kelompok peneliti). Evaluasi hasil penelitian dapat dilakukan dan sangat tergantung kepada ketersediaan dan kehandalan data yang berkaitan dengan hasil kegiatan penelitian ilmiah yang dilakukan dengan baik. Indikator bibliometrik merupakan pengetahuan yang dapat digunakan untuk mengevaluasi hasil penelitian 
ilmiah. Secara luas digunakan untuk mengkaji interaksi antara ilmu pengetahuan dan teknologi; menghasilkan pemetaan bidang ilmu; dan untuk melacak atau menelusuri perkembangan pengetahuan baru dalam bidang tertentu; serta merupakan indikator di masa depan dalam memberikan keuntungan yang lebih kompetitif dan dalam membuat rencana strategis. Pada awalnya bibliometrika dan scientometrika diperkenalkan oleh Pritchard dan Nalimov dan Mulchencko pada tahun 1969. Pritchard mengatakan bahwa bibliometrika adalah metode yang menggunakan matematika dan statistik terhadap buku dan media komunikasi lainnya. Sementara Nalimov and Mulchenko mengartikan bahwa scientometrika adalah metode kualitatif yang berkenaan dengan analisis dari ilmu pengetahuan sebagai proses informasi (Glanzel, 2003). Scientometrics secara khusus digunakan untuk mengukur komunikasi ilmiah, dimana bibliometrika didesain secara lebih umum terhadap proses informasi. Perkembangan berikutnya dari bibliometrika adalah informetrika yang juga berkaitan dengan media elektronik dan oleh karena itu termasuk di dalamnya adalah penggunaan analisis statistik dari sistem teks maupun hypertext, pengukuran informasi dari perpustakaan elektronik (Glanzel, 2003).

Menurut Glanzel, 2003, terdapat tiga komponen dari bibliometrika yaitu; a) Bibliometrics for bibliometricians, ini merupakan domain utama dari riset bibliometrika dan secara tradisional digunakan sebagai metodologi riset; b) Bibliometrics for scientific disciplines (scientific information). Peneliti dengan berbagai ilmu yang sangat bervariasi dapat dikelompokkan dalam grup menggunakan metode bibliometrik. Mengingat para peneliti bekerja berorientasi secara ilmiah, ketertarikan mereka sangat kuat di bidang spesialisasinya, sehingga dimungkinkan adanya joint borderland dengan riset kuantitatif dalam penelusuran informasi (information retrieval); c) Bibliometric for science policy and management (science policy), hal ini merupan domain dari evaluasi riset, saat ini terdapat banyak topik di dalam penelitian. Secara institusional, nasional, regional, struktur dari sini nantinya dapat diperbandingkan.

Pemetaan merupakan sebuah proses yang memungkinkan seseorang mengenali elemen pengetahuan serta konfigurasi, dinamika, ketergantungan timbal-balik, dan interaksinya. Pemetaan pengetahuan digunakan untuk keperluan manajemen teknologi, mencakup definisi program penelitian, keputusan menyangkut aktivitas yang berkaitan dengan teknologi, desain struktur basis pengetahuan, serta pembuatan program pendidikan dan pelatihan. Dalam kaitannya dengan bibliometrika, pemetaaan ilmu pengetahuan merupakan metode visualisasi sebuah bidang ilmu. Visualisasi ini dilakukan dengan menciptakan peta lanskap. Dalam peta akan muncul topik dari ilmu pengetahuan. Masukannya adalah data bibliografis, keyword, sitasi, dll. (Sulistiyo-Basuki, 2001). Peta ilmu pengetahuan dapat dibuat sedemikian rupa sehingga memperlihatkan pertumbuhan suatu bidang ilmu tertentu. Hal ini dimaksudkan agar dapat membantu peneliti untuk menyusun program penelitiannya sendiri (SulistiyoBasuki, 1989). Konsep ilmu pengetahuan yang terkandung dalam suatu dokumen 
terlihat melalui kata-kata yang digunakan. Analisis co-word didasarkan pada analisis co-occurrence kata atau kata kunci dari dua atau lebih dokumen yang digunakan untuk mengindeks dokumen (Diodato, 1994). Analisis co-word ditujukan untuk menganalisis isi, pola dan kecenderungan (trend) dari suatu kumpulan dokumen dengan mengukur kekuatan istilah (term) (De Looze, Lemarie, 1997; Coulter, Monarch, Konda, 1998)

Analisis co-word digunakan untuk menghitung banyaknya kata kunci dari suatu dokumen penelitian yang muncul secara bersamaan pada makalah- makalah yang diteliti. Kata kunci ini umumnya dipilih penulis. Semakin banyak munculnya kata kunci pada sekelompok dokumen yang telah ditentukan, semakin kuat hubungan antara dokumendokumen tersebut (Chen, 2003). Peta berdasarkan analisis co-word dari kata kunci adalah peta yang didasarkan atas co-occurrence istilah-istilah penting atau unik yang terdapat dalam artikel dan bisa dilihat dengan melihat judul atau abstraknya saja. Istilah yang didapat dari analisis subjek mewakili suatu konsep. Penggunaan kata kunci yang tidak distandarkan akan menimbulkan istilahistilah yang tidak seragam. Untuk menstandarkannya digunakan tesaurus dan istilah yang mewakili konsep atau dinamakan deskriptor. Tesaurus adalah daftar istilah yang mencakup satu bidang khusus sehingga istilah yang digunakan bisa lebih spesifik, berbeda dengan daftar tajuk subjek yang biasanya bersifat umum dan mencakup semua bidang ilmu pengetahuan. Pada pengindeksan dengan menggunakan deskriptor, diusahakan agar tiap deskriptor mewakili konsep tunggal. Menstandarkan kata kunci dengan tesaurus dimaksudkan agar kata yang digunakan konsisten sehingga hanya digunakan satu istilah untuk konsep yang diwakili tulisan berbeda, tetapi memiliki arti yang sama.

Penelitian terdahulu yang pernah dilakukan adalah Hongjiang Yue (2012) menggunakan analisis text mining dan coword untuk menunjukkan pola dan tren dalam manajemen pengetahuan internasional. Murray et al. (2006) memetakan bidang ilmiah dan keahlian penulis berdasarkan data bibliografi menggunakan InfoVis Cyberinfrastructure, Geomi dan Pajek.

Kajian ini bertujuan untuk mengetahui peta perkembangan penelitian pemanfaatan repositori institusi menuju open access. Kajian dilakukan dengan cara melakukan penelusuran melalui database scopus dengan kata kunci open access dan repository institutions. Data hasil penelusuran tersebut kemudian dianalisis secara deskriptif berdasarkan tahun terbit publikasi, nama lembaga dan negara yang mempublikasikan hasil penelitian perkembnangan penelitian pemanfaatan repositori institusi menuju open access, nama jurnal/publikasi, tipe dokumen, dan topik penelitian. Untuk mendapatkan peta perkembangan penelitian, data tersebut di-export dalam format CSV (Comma Separated Values) file. Data hasil export kemudian diolah dan dianalisis menggunakan program aplikasi VOSViewer untuk mengetahui peta bibliometrik perkembangan penelitian pemaanfaatan repositori institusi menuju open access.

\section{METODOLOGI PENELITIAN}

Kajian ini dilakukan dengan cara melakukan penelusuran melalui database Scopus (https://www.scopus.com/). Penelusuran pada database Scopus 
menggunakan istilah atau kata kunci open access dan repository institutions melalui ruas pencarian "Document search", sebagaimana terlihat pada Gambar 1.

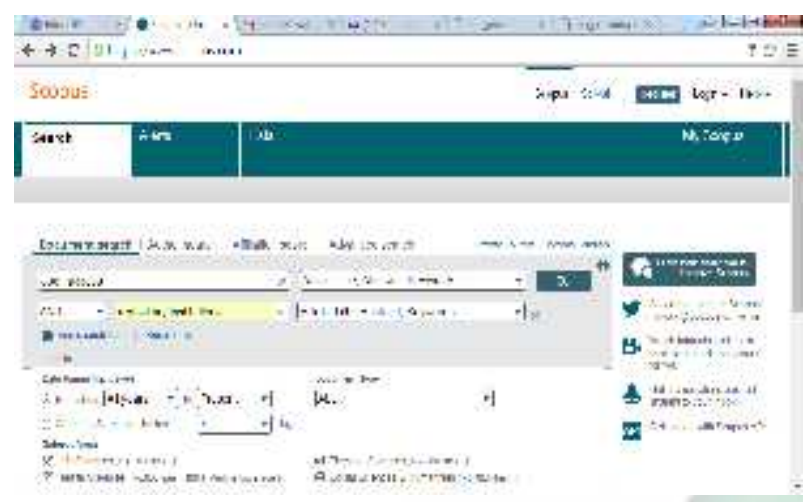

Gambar 1. Cara melakukan penelusuran open access dan repositori institutions

Berdasarkan Gambar 2, diketahui sebanyak 325 artikel/publikasi ilmiah perkembangan penelitian pemanfaatan repositori institusi menuju open access yang terindeks Scopus pada tahun 19862016. Sejumlah data tersebut kemudian dianalisis secara deskriptif berdasarkan tahun terbit publikasi, lembaga yang mempublikasikan, negara yang mempublikasikan, nama jurnal/publikasi, tipe dokumen, dan topik penelitian. Untuk mendapatkan peta penelitian, data tersebut di-export dalam format CSV (Comma Separated Values) file. Data hasil export kemudian diolah dan dianalisis menggunakan program aplikasi VOSViewer untuk mengetahui peta bibliometrik perkembangan penelitian pemaanfaatan repositori institusi menuju open access.

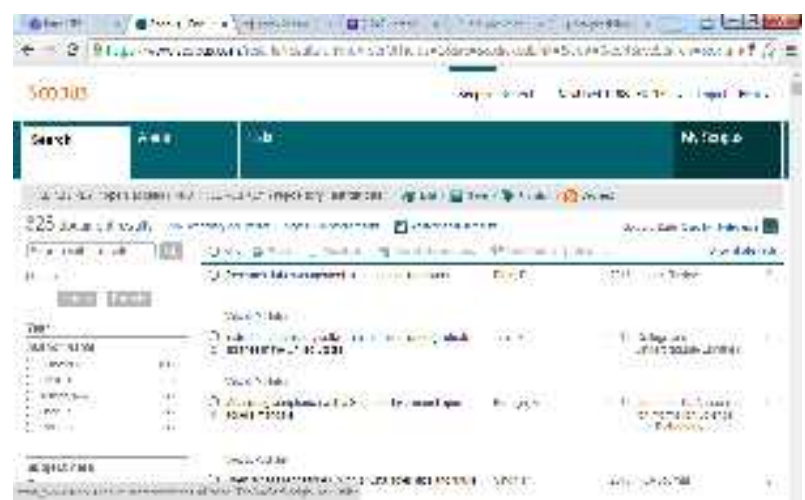

Gambar 2. Tampilan hasil penelusuran perkembangan repositori institusi menuju open access

\section{HASIL DAN PEMBAHASAN}

\section{a. Tahun Terbit Perkembangan Penelitian Pemanfaatan Repositori Institusi Menuju Open Access.}

Dari hasil penelusuran melaui database scopus menunjukkan bahwa perkembangan repositori menuju open access telah ada sejak tahun 1986. Mulai tahun 1987 sampai dengan tahun 1993 tidak ada penelitian tentang perkembangan repositori institusi menuju open access. Kemudian tahun 1994 ada satu penelitian dan mulai tahun 1995 sampai tahun 2001 juga tidak ada penelitian. Mulai tahun 2002 sampai dengan tahun 2016 penelitian tentang perkembangan repositori mengalami peningkatan yang sangat significan. Untuk lebih jelasnya perkembangan penelitian repository lembaga menuju open acces dapat dilihat pada Tabel 1 dan Gambar 3.

Tabel 1. Jumlah penelitian perkembangan pemanfaatan repositori institusi menuju open acces berdasarkan tahun

\begin{tabular}{|c|c|}
\hline Tahun Terbit & Jumlah \\
\hline 2016 & 17 \\
\hline
\end{tabular}




\begin{tabular}{|c|c|}
\hline 2015 & 33 \\
\hline 2014 & 44 \\
\hline 2013 & 36 \\
\hline 2012 & 31 \\
\hline 2011 & 26 \\
\hline 2010 & 27 \\
\hline 2009 & 29 \\
\hline 2008 & 23 \\
\hline 2007 & 22 \\
\hline 2006 & 22 \\
\hline 2005 & 7 \\
\hline 2004 & 3 \\
\hline 2003 & 2 \\
\hline 2002 & 1 \\
\hline 2001 & 0 \\
\hline 2000 & 0 \\
\hline 1999 & 0 \\
\hline 1998 & 0 \\
\hline 1997 & 0 \\
\hline 1996 & 0 \\
\hline 1995 & 0 \\
\hline 1994 & 1 \\
\hline 1993 & 0 \\
\hline 1992 & 0 \\
\hline 1991 & 0 \\
\hline 1990 & 0 \\
\hline 1989 & 0 \\
\hline 1988 & 0 \\
\hline
\end{tabular}

\begin{tabular}{|l|l|}
\hline 1987 & 0 \\
\hline 1986 & 1 \\
\hline
\end{tabular}

Dari Tabel 1 dan Gambar 3 menunjukkan bahwa perkembangan penelitian pemanfaatan repositori institusi menuju open acces sudah ada sejak tahun 1986 yang dilakukan oleh Geselbracht, R.H dengan Judul artikel "The origins of restrictions on access to personal papers at the library of congress and the national archives". Yang pada intinya Geselbracht (1986) mengatakan bahwa bahwa suatu kebijakan akses yang dikembangkan dalam tradisi arsip publik, didasarkan pada asumsi bahwa kertas dengan konten kebijakan publik yang tinggi harus terbuka.

\section{Eambar 3, Jumlah Pu dikasi Berdasarkan Tahun.}

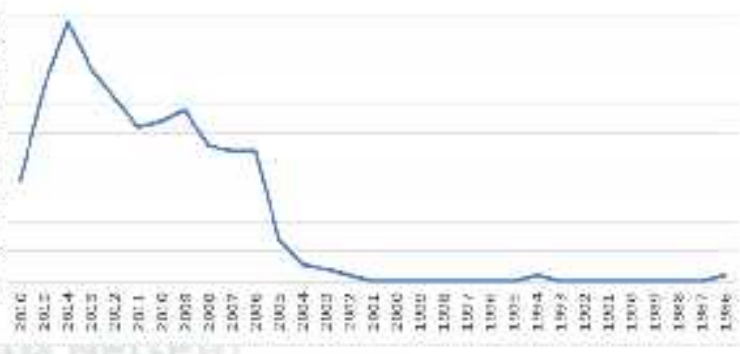

Gambar 3. Jumlah publikasi berdasarkan tahun

\section{b. Nama Jurnal Yang Memuat Publikasi Perkembangan Penelitian Pemanfaatan Repositori Institusi Menuju Open Access}

Dari hasil penelusuran informasi di Scopus diketahui bahwa publikasi yang memuat perkembangan hasil penelitian pemanfaatan repositori institusi menuju open access sebagian besar adalah jurnal. Dari tahun 1986-sampai dengan Agustus 2016 diketahui ada sebanyak 110 jurnal yang memuat publikaasi perkembangan hasil penelitian repositori institusi menuju 
open access, hal tersebut dapat dilihat pada Tabel 2.

Tabel 2. Nama jurnal yang memuat publikasi perkembangan penelitian pemanfaatan repositori institusi menuju open access

\begin{tabular}{|l|c|}
\hline Nama Publikasi & Jumlah \\
\hline OCLC Systems And Services & 13 \\
\hline $\begin{array}{l}\text { Lecture Notes In Computer Science } \\
\text { Including Subseries Lecture Notes In } \\
\begin{array}{l}\text { Artificial Intelligence And Lecture } \\
\text { Notes In Bioinformatics }\end{array}\end{array}$ & 12 \\
\hline Grey Journal & 8 \\
\hline \hline Information Services And Use & 7 \\
\hline Liber Quarterly & 6 \\
\hline Library Review & 6 \\
\hline Program & $\underline{5}$ \\
\hline Serials Librarian & 6 \\
\hline $\begin{array}{l}\text { Desidoc Journal Of Library And } \\
\text { Information Technology }\end{array}$ & \\
\hline Library Hi Tech & \\
\hline
\end{tabular}

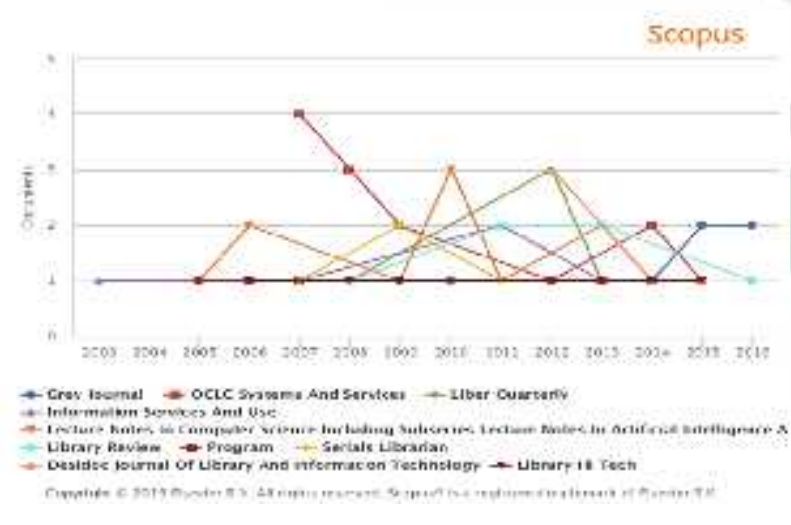

Gambar 4. Grafik nama jurnal yang memuat perkembangan penelitian pemanfaatan repositori

Dari Tabel 2 dan Gambar 4 menunjukkan bahwa dari 10 jurnal terbanyak yang mempublikasikan artikel penelitian perkembangan pemanfaatan repositori menuju open access adalah jurnal OCLC Systems And Services merupkan jurnal yang paling banyak mempublikasikan artikel penelitian perkebangan penelitian pemanfaatan repositori institusi menuju open access yaitu sebanyak 13 artikel. Peringkat kedua adalah Lecture Notes In Computer Science Including Subseries Lecture Notes In Artificial Intelligence And Lecture Notes In Bioinformatics sebanyak 12 artikel, disusul Grey Journal 8 artikel dan Information Services And Use 7 artikel, Liber Quarterly, Library Review, Program dan Serial Libraian masing - masing 6 artikel, Desidoc Journal of Library And Information Technology dan Library $\mathrm{Hi}$ Tec masingmasing 5 artikel.

\section{c. Peringkat 10 Terbanyak Lembaga Yang Perkembangan Mempublikasikan Pemanf Menuju Open Access}

Berdasarkan hasil analisis menunjukkaan bahwa lembaga/afiliasi yang paling banyak mempublikasikan artikel perkembangan penelitian pemanfaatan repositori institusi menuju open access adalah Universite Charles de Gaulle Lille 3, Universitat Wien, University of Southampton dan Universitat de Barcelona. Perbandingan 10 Lembaga/Afiliasi yang paling banyak mempublikasikan artikel penelitian perkembangan repositori institusi menuju open access dapat dilihat pada Tabel 3 berikut.

Tabel 3. Nama peringkat 10 terbanyak lembaga yang mempublikasikan perkembangan penelitian pemanfaatan repositori institusi menuju open access

\begin{tabular}{|l|c|}
\hline Afiliasi/ Lembaga & Jumlah \\
\hline Universite Charles de Gaulle Lille & 9 \\
\hline
\end{tabular}




\begin{tabular}{|l|c|}
\hline 3 & 7 \\
\hline Universitat Wien & 6 \\
\hline University of Southampton & 5 \\
\hline Universitat de Barcelona & 4 \\
\hline University of Amsterdam & 4 \\
\hline Blekinge Tekniska Hogskola & 4 \\
\hline Universiteit van Pretoria & 4 \\
\hline \hline University of Malaya & 3 \\
\hline Universitat Gottingen & Akademie der Bildenden Kunste \\
\hline Wien
\end{tabular}

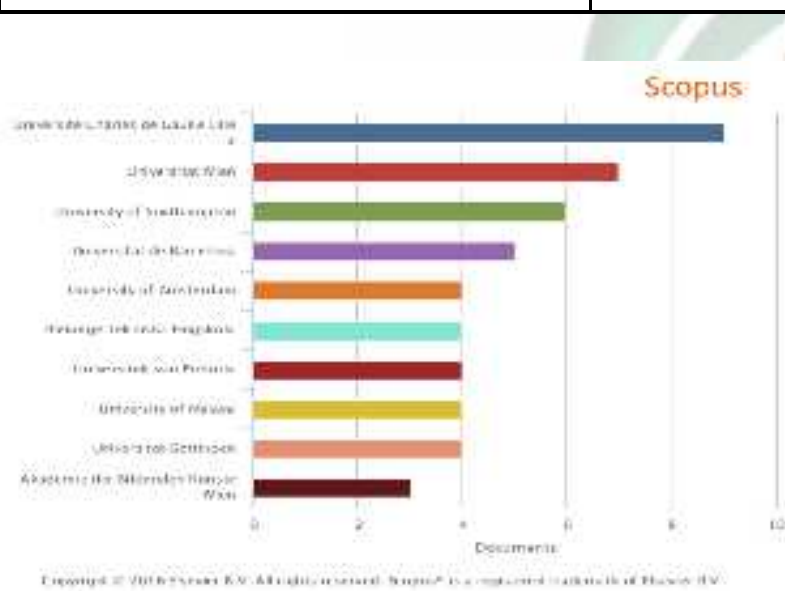

Gambar 5. Grafik peringkat 10 terbanyak lembaga yang mempublikasikan penelitian perkembangan repositori institusi menuju open access

Dari Tabel 3. dan Gambar 5. menunjukkan bahwa afiliasi/lembaga yang terbanyak mempublikasikan artikel penelitian perkembangan repositori institusi menuju open access adalah Universite Charles de Gaulle Lille 3 adalah sebanyak 9 artikel, disusul Universitat Wien 7 artikel, University of Southampton 6 artikel, Universitat de Barcelona 5 artikel, University of Amsterdam, Blekinge Tekniska Hogskola, Universiteit van Pretoria, dan University of Malaya masing-masing 4 artikel.

\section{d. Peringkat Negara Terbanyak yang Mempublikasikan Perkembangan Penelitian Repositori Institusi Menuju Open Acees}

Berdasarkan hasil analisis penelusuran melalui database scopus menunjukkan bahwa negara yang terbanyak mempublikasikan artikel perkembangan penelitian repositori institusi menuju open access adalah United States, disusul United Kingdom, India, Spain, Italy dan Australia. Untuk lebih jelasnya mengenai peringkat negara yang mempublikasikan perkembangan penelitian repositori menuju open access dapat dilihat pada Tabel 4 Berikut.

Tabel 4. Nama negara terbanyak yang mempublikasikan penelitian perkembangan repositori institusi menuju open access

\begin{tabular}{|c|c|}
\hline Nama Negara & Jumlah \\
\hline United States & 53 \\
\hline United Kingdom & 33 \\
\hline India & 28 \\
\hline Spain & 26 \\
\hline Italy & 17 \\
\hline Undefined & 17 \\
\hline Australia & 16 \\
\hline Germany & 16 \\
\hline Canada & 14 \\
\hline France & 13 \\
\hline Brazil & 11 \\
\hline South Africa & 11 \\
\hline Austria & 9 \\
\hline Netherlands & 9 \\
\hline
\end{tabular}


Dari Tabel 4. dan Gambar 6. terlihat bahwa Uninetd States merupakan negara yang paling banyak mempublikasikan artikel perkembangan penelitian repositori institusi menuju open access yaitu sebanyak 53 artikel. Disusul United Kingdom sebanyak 33 artikel, India sebanyak 28 artikel dan Italy sebanyak 17 artikel.

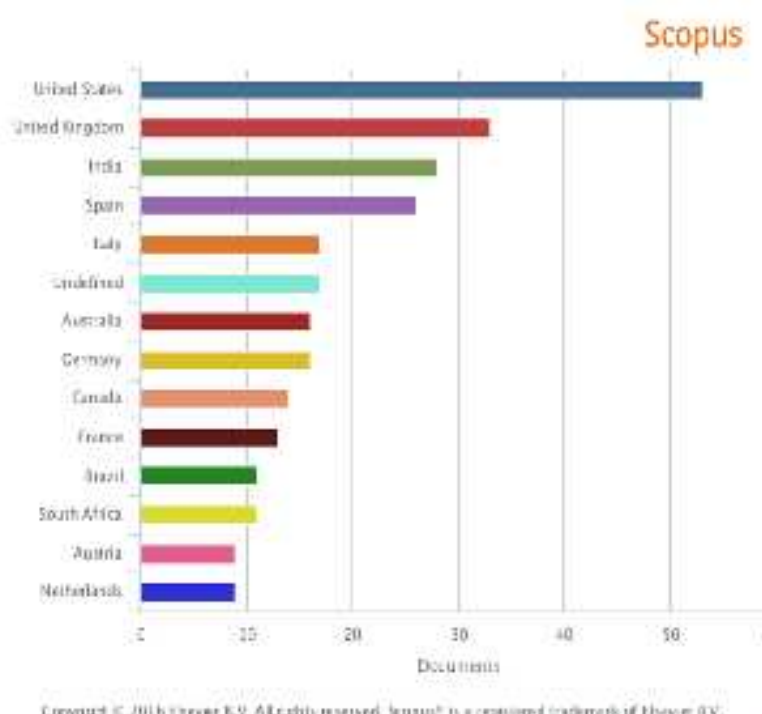

Gambar 6. Nama Negara Terbanyak yang Mempublikasikan Penelitian

\section{e. Tipe Dokumen Publikasi Penelitian Perkembangan Repositori Institusi Menuju Open Access}

Berdasarkan hasil penelusuran melalui database scopus diperoleh artikel hasil penelitian perkembangan repositori intitusi menuju open access sebanyak 325 judul. Berdasarkan tipe dokumen artikel merupkan jumlah terbanyak, kemudian disusul Conference Paper dan Review. Untuk lebih jelasnya jumlah publikasi penelitian perkembangan repositori institusi menuju open access dapat dilihat pada Tabel 4 . berikut.
Tabel 5. Jumlah Publikasi Penelitian Perkembangan Repositori Institusi Menuju Open Access Berdasarkan Tipe Dokumen

\begin{tabular}{|c|c|}
\hline Document Type & Documents \\
\hline \hline Article & 185 \\
\hline Conference Paper & 97 \\
\hline Review & 26 \\
\hline Book Chapter & 6 \\
\hline Conference Review & 6 \\
\hline Note & 2 \\
\hline Short Survey & 2 \\
\hline Editorial & 1 \\
\hline Total & 325 \\
\hline
\end{tabular}

Scopus

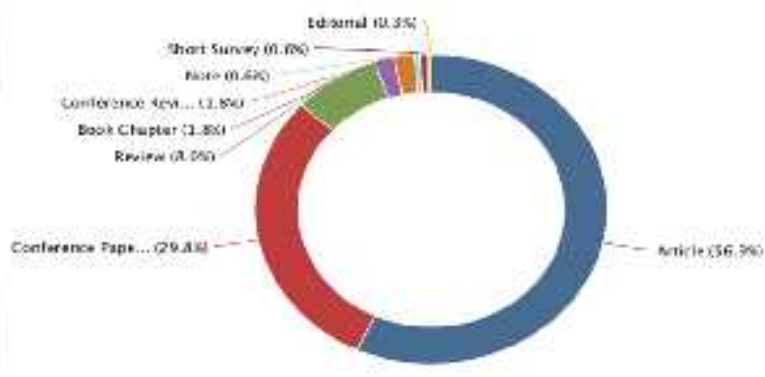

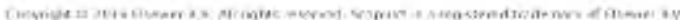

Gambar 7. Jumlah publikasi penelitian perkembangan repositori institusi menuju open access berdasarkan tipe dokumen

\section{f. Topik Perkembangan Penelitian Pemanfaatan Repositori Institusi Menuju Open Access}

Setelah dilakukan analisis subjek untuk menentukan bidang dari setiap penelitian perkembangan repositori institusi menuju open access, ditemukan 38 topik atau bidang penelitian seperti yang terlihat pada Tabel 6 . 
Tabel 6. Topik perkembangan penelitian pemanfaatan repositori institusi menuju open access

\begin{tabular}{|c|c|c|c|}
\hline No & Keyword & Jumlah & Persentase \\
\hline 1 & Open Access & 132 & 14,73 \\
\hline 2 & $\begin{array}{l}\text { Institutional } \\
\text { Repositories }\end{array}$ & 109 & 11,16 \\
\hline 3 & $\begin{array}{l}\text { Societies And } \\
\text { Institutions }\end{array}$ & 82 & 9,15 \\
\hline 4 & $\begin{array}{l}\text { Information } \\
\text { Services }\end{array}$ & 68 & 7,59 \\
\hline 4 & Research & 36 & 4,02 \\
\hline 5 & Digital Libraries & 33 & 3,68 \\
\hline 6 & $\begin{array}{l}\text { Institutional } \\
\text { Repository }\end{array}$ & 28 & 3,13 \\
\hline 7 & Metadata & 24 & 2,68 \\
\hline 8 & $\begin{array}{l}\text { Electronic } \\
\text { Publishing }\end{array}$ & 23 & 2,57 \\
\hline 9 & $\begin{array}{l}\text { Scholarly } \\
\text { Communication }\end{array}$ & 23 & 2,57 \\
\hline 10 & $\begin{array}{l}\text { World } \quad \text { Wide } \\
\text { Web }\end{array}$ & $21 \div$ & 2,34 \\
\hline 11 & Education & 19 & 2,12 \\
\hline 12 & Open Systems & 18 & 2,01 \\
\hline 13 & Publishing & 17 & 1,90 \\
\hline 14 & Libraries & 14 & 1,56 \\
\hline 15 & Digital Storage & 13 & 1,45 \\
\hline 16 & $\begin{array}{l}\text { Electronic } \\
\text { Document } \\
\text { Exchange }\end{array}$ & 13 & 1,45 \\
\hline
\end{tabular}

\begin{tabular}{|c|c|c|c|}
\hline 17 & Article & 12 & 1,34 \\
\hline 18 & Human & 12 & 1,34 \\
\hline 19 & $\begin{array}{l}\text { Information } \\
\text { Management }\end{array}$ & 12 & 1,34 \\
\hline 20 & Internet & 12 & 1,34 \\
\hline 21 & Repository & 12 & 1,34 \\
\hline 22 & $\begin{array}{l}\text { Academic } \\
\text { Libraries }\end{array}$ & 11 & 1,23 \\
\hline 23 & Humans & 11 & 1,23 \\
\hline 24 & India & 11 & 1,23 \\
\hline 25 & $\begin{array}{l}\text { Digital } \\
\text { Preservation }\end{array}$ & 10 & 1,11 \\
\hline 26 & Grey Literature & 10 & 1,11 \\
\hline 27 & $\begin{array}{l}\text { Information } \\
\text { Dissemination }\end{array}$ & 10 & 1,11 \\
\hline 28 & $\begin{array}{l}\text { Open Source } \\
\text { Software }\end{array}$ & 10 & 1,11 \\
\hline 29 & Repositories & 10 & 1,11 \\
\hline 30 & Research Data & 10 & 1,11 \\
\hline 31 & $\begin{array}{l}\text { Academic } \\
\text { Institutions }\end{array}$ & 9 & 1,00 \\
\hline 32 & $\begin{array}{l}\text { Developing } \\
\text { Countries }\end{array}$ & 9 & 1,00 \\
\hline 33 & $\begin{array}{l}\text { Digital } \\
\text { Repository }\end{array}$ & 9 & 1,00 \\
\hline 34 & $\begin{array}{l}\text { Information } \\
\text { Retrieval }\end{array}$ & 9 & 1,000 \\
\hline 35 & $\begin{array}{l}\text { Information } \\
\text { Systems }\end{array}$ & 9 & 1,00 \\
\hline 36 & Interoperability & 9 & 1,00 \\
\hline 37 & $\begin{array}{ll}\text { Access } & \text { To } \\
\text { Information } & \end{array}$ & 8 & 0,89 \\
\hline 38 & Archiving & 8 & 0,89 \\
\hline
\end{tabular}


Dari Tabel 7.dan Gambar 8.menunjukkan bahwa dalam perkembangannya repositori institusi menuju open access, topik yang paling banyak diteliti dalam database scopus adalah open access yaitu sebanyak 132 judul (14,73\%), kemudian diikuti oleh topik institusional repositories sebanyak 109 judul $(11,16 \%)$, societies And institutions sebanyak 82 judul $(9,15)$. Adapun topik lain yang mendukung perkembangan open access adalah information services 68 judul (7,59\%), research 36 judul $(4,02 \%)$, digital libraries 33 judul $(3,68 \%)$, metadata 24 judul $(2,68 \%)$, electronic publishing dan scholarly communication masing-masing 23 judul $(2,57 \%)$, word wide web 21 judul $(2,34 \%)$, education 19 judul $(2,12 \%)$ dan open system 18 judul (2,01\%). Hal tersebut sesuai dengan pendapat Richard Johnson dalam Kurniawan (2015) mendefinisikan repositori institusi dalam suatu komunitas perguruan tinggi, yaitu sebagai arsip digital dari produk intelektual yang dihasilkan oleh dosen, peneliti dan mahasiswa untuk memberikan kemudahan akses baik bagi pengguna dari dalam institusi maupun dari luar institusi dengan sedikit hambatan (open access).

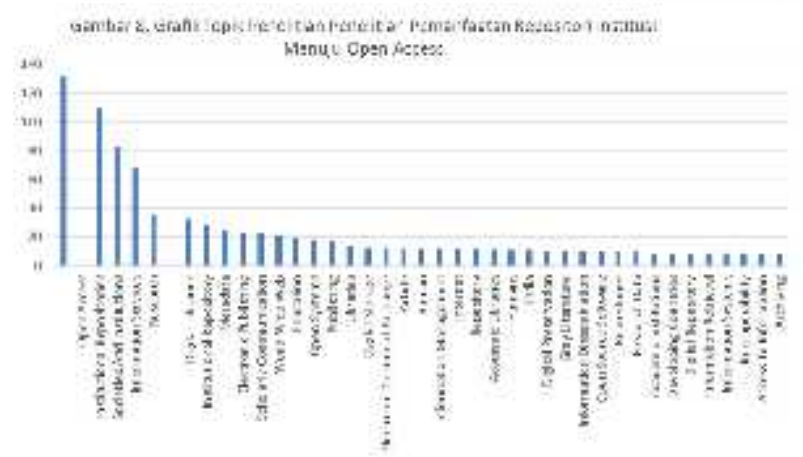

Gambar 8. Publikasi penelitian perkembangan repositori institusi menuju open access berdasarkan topik

\section{g. Peta co-word Perkembangan Penelitian Pemanfaatan Repositori Institusi Menuju OpenAccess}

Dari hasil penelusuran dari database scopus sebanyak 325 dokumen kemudian di-export ke format CSV, di-input dan dianalisis dengan VOSViewer diperoleh hasil sebagai berikut.

\section{Visualisasi network Peta Co-word}

Hasil analisis peta co-word dari kata kunci ini menjadi dasar pemetaan cooccurrence terhadap istilah-istilah yang penting atau unik yang terdapat dalam artikel tertentu. Pemetaan merupakansebuah proses yang memungkinkan seseorang mengenali elemen pengetahuan serta konfigurasi, dinamika, ketergantungan timbal-balik, dan interaksinya. Pemetaan pengetahuan digunakan untuk keperluanmanajemen teknologi, yang mencakup definisi program penelitian, keputusan terkait aktivitas teknologi, desain struktur basispengetahuan, serta pembuatan program pendidikan dan pelatihan. Terkait dengan bibliometrika, pemetaaan ilmu pengetahuan merupakan metodevisualisasi sebuah bidang ilmu. Visualisasi ini dilakukan dengan menciptakan peta lanskap yang dapat menampilkan topik dari ilmu pengetahuan (Royani, et al., 2013). Hasil visualasi network peta co-word penelitian perkembangan pemanfaatan repository institusi menuju open access dapat dilihat pada Gambar 9. berikut. 


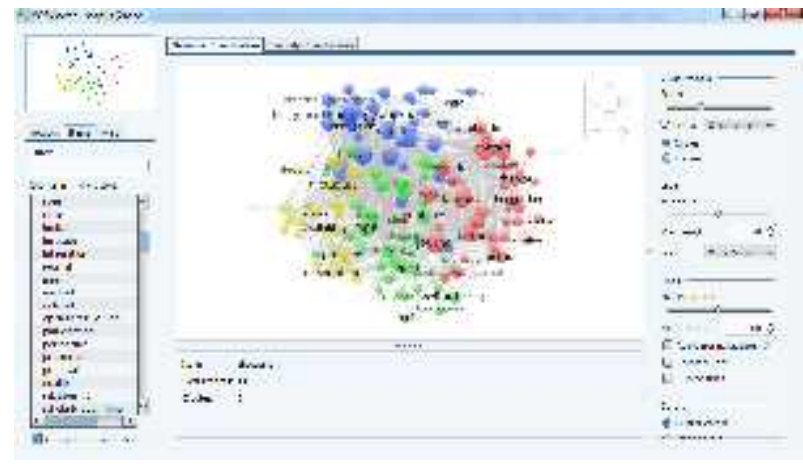

Gambar 9. Visualisasi network peta perkembangan penelitian pemanfaatan repositori insititusi menuju open access

Dari Gambar 9. menujukkan bahwa peta perkembangan penelitian pemanfaatan repository institusi menuju open access terbagi menjadi 4 kluster sebagai berikut.

- Kluster 1 warna merah terdiri dari 41 topik diantarnya adalah academic, adoption, application, book, citation, collaboration, conference, database, journal, network, open access journal, scholary publishing, scientific production, scientific research, scientist, society, trend, university library dan web.

- Kluster 2 warna hijau terdiri dari 40 topik diantaranya adalah design methology approach, enteroperability, librarian, literature, museum, open access movement, open source software, originality value, practical implication, recommendation, repository manager, research limitations implication, reseach ouput, scholarly communications, dan software.

- Kluster 3 warna biru terdiri dari 35 topik diantaranya adalah accessibility, copyright, digital repository, faculty, free access, open access journal, open acces publishing, open access repositories, opendoar, publisher, research data, research result, dan sefl archiving,

- Kluster 4 warna kuning terdiri dari 27 topik diantaranya adalah academic institutions, cultural heritage, deposit, digital library, dissertation, electronic thesis, fult text, grey literature, metadata, open access initiative, scientific community, scientific information, dan thesis.

\section{Visualisasi Density Peta Co-word}

The cluster density view, merupakan item (label) yang ditandai sama dengan item yang terlihat. Setiap titik item memiliki warna yang tergantung pada kepadatan item pada saat itu. Hal tersebut mengidentifikan bahwa warna titik di peta tergantung pada jumlah item yang terkait dengan item lain. Bagian ini sangat berguna untuk memperoleh gambaran dari struktur umum peta bibliometrik dengan memperhatikan bagian item yang dianggap penting untuk dianalisis. Melalui lembar kerja ini, kita dapat menafsirkan keywords yang paling banyak digunakan dalam suatu publikasi. Visualisasi density peta co-word perkembangan penelitian pemanfaatan repository institusi menuju open access dapat dilihat pada Gambar 10. berikut.

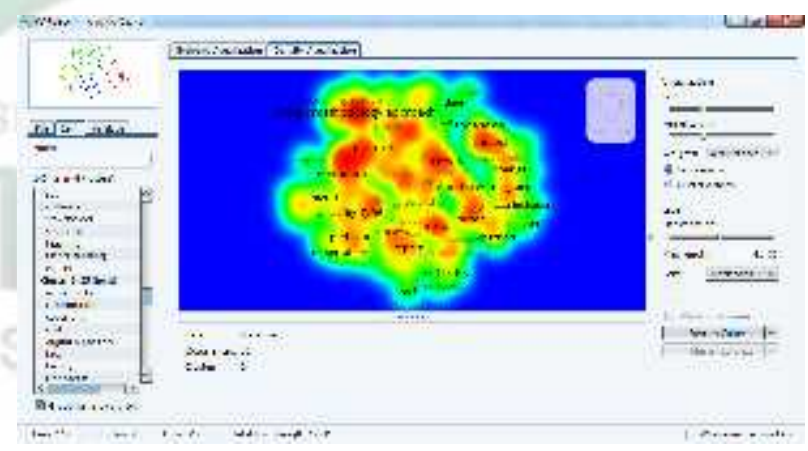

Gambar 10. Visualisasi density perkembangan penelitian pemanfaatan repositori insititusi menuju open access

Gambar 10 di atas menunjukkan peta densitas yang merupakan hasil analisis yang menggunakan seluruh artikel perekembangan penelitian pemanfaatan repositori institusi menuju open access, baik yang berhubungan maupun yang 
tidak berhubungan. Makin merah makin rapat, dan makin hijau makin jarang. Dalam gambar tersebut akan ada 4 kluster bila disortasi berdasarkan kata kuncinya.

\section{KESIMPULAN}

Berdasarkan hasil dan pembahasan di atas dapat disimpulkan bahwa perkembangan penelitian pemanfaatan repositori institusi menuju open access yang terindeks di Scopus mulai ada tahun 1986. Mulai tahun 2002-2016 perkembangan penelitian pemanfaatan repositori institusi menuju open access meningkat secara signifikan. Journal yang paling banyak mempublikasikan perkembangan penelitian repositori menuju open access adalah OCLC System and Services, Lecture Notes in Compuer Science, Grey Journal, Information Services and Use, Liber Quarterly, Library Review dan Serial Librarian. Dilihat dari jenis/tipe dokumen yang banyak diteliti adalah dalam bentuk artikel disusul conference paper, review dan book chapter. Bidang atau topik yang paling dominan adalah open access, institutional repositorries, societies and institutions, information services, digital libraries, metadata, dan electronic publishing. Melalui visualisai network menunjukkan bahwa hubungan antartopik diperlihatkan dengan garis antardeskriptor pada masing-masing bidang. Semakin banyak garis hubungan antardeskriptor semakin dekat hubungan antardokumen. Sementara dengan visualisasi density menunjukkan bahwa hubungan antartopik makin merah makin rapat dan makin hijau makin jarang.

\section{DAFTAR PUSTAKA}

Anwarul Islam, MD. (2013). Institutional Repositories and Open Access Initiatives in Bangladesh: A New
Paradigm of Scholarly Communication. Liber Quartely. Vol.23, no. 1 (2013) 3-24

Chen, Chaomei. 2003. Mapping scientific: the quest for knowledge visulization. London, SpringerVerlag. 223p.

De Looze, M.A., and Lemarie, J. 1997. Corpus relevance through co-word analysis:an application to plants. Scientometrics, 39 (3): 267-280.

Geselbracht, R.H. 1986. The origins of restrictions on access to personal papers at the library of congress and the national archives. American Archivist. Volume 49, 2, 1 April 1986, Pages 142-162

Hongjiang Yue (2012). Mapping The Intellectual Structure by Co-Word: A Case Of International Management Science

Glanzel, W. 2003. Bibliometrics As A Research Field : A course on theory and application of bibliometric indicators. Dalam http://nsdl.niscair.res.in/jspui. Diakes tanggal 21 Desember 2015.

Kurniawan, Taufiq. 2015. Pengembangan Directory of Open Access Repositories di Indonesia (Upaya integrasi konsep institutional repository dan open access sebagai model kolaborasi antarinstitusi).

Murray et al. (2006). Mapping Scientific Disciplines And Author Expertise Based On Personal Bibliography Files. Tenth International Conference On Information Visualization, London

Royani, Yupi; Mulni A. Bachtar; Kamariah Tambunan; Tupan; dan Sugiharto. 2013. Pemetaan Karya Tulis Ilmiah LPNK: Studi Kasus LIPI dan BPPT (2004-2008).BACA: Jurnal 
Dokumentasi dan Informasi, 34 (1) Juni.

Russell, Jane M. And Ronald Rousseau. 2015. Bibliometrics and Institutional

Evaluation. Diakses dari

http://www.universitario.mexico.

Pada tanggal 19 Desember 2015

Sulistyo-Basuki. 1989. Komunikasi ilmiah: dari surat pribadi sampai majalah. Majalah Ilmu Perpustakaan dan Informatika, 4 (1-2): 11 -19. 